\title{
Pelatihan Peningkatan Produksi Peternakan Ruminansia Desa Jarak Kecamatan Plosoklaten Kabupaten Kediri
}

\author{
Ertika Fitri Lisnanti ${ }^{1}$, Amiril Mukmin ${ }^{2}$ \\ Universitas Islam Kadiri \\ email : ertika@uniska-kediri.ac.id ${ }^{1}$ dan amiril@uniska-kediri.ac.id ${ }^{2}$
}

\begin{abstract}
Kediri District Government has tried to increase the capacity, skills, and income of the community. One of these efforts is holding training provided by the Food and Animal Husbandry Service of Kediri Regency. The topic of the training is "Increasing Ruminant Animal Production by the Food Security and Animal Husbandry Service of Kediri Regency". This activity in collaboration with the Kadiri Islamic University in the Community Service. The type of community service is as a speaker in this training activity. The subject matter in simple handling of reproductive disorders and livestock health and making beef cattle feed. The training lasted for two days with sessions providing material, question and answer, and practice. The training activities went well and smoothly and conducive. This activity can add insight to breeders to increase their production. As a result of this training process, breeders can prevent cases of the disease in their livestock and can make simple ruminant animal feed with nutrition.
\end{abstract}

Keywords: training, animal production, ruminants.

\begin{abstract}
Abstrak
Pemerintah Kabupaten Kediri terus berupaya dalam peningkatan kemampuan, ketrampilan dan pendapatan masyarakat. Upaya tersebut salah satunya yaitu mengadakan pelatihan yang diberikan oleh Dinas Ketahanan Pangan dan Peternakan Kabupaten Kediri. Pelatihan tersebut memiliki tema Peningkatan Produksi Peternakan Ruminansia oleh Dinas Ketahanan Pangan dan Peternakan Kabupaten Kediri. Kegiatan ini bekerjasama dengan Universitas Islam Kadiri dalam bentuk Pengabdian kepada Masyarakat. Bentuk pengabdian yaitu sebagai pemateri dalam kegiatan pelatihan ini. Materi yang disampaikan berupa pelatihan penanganan sederhana dari gangguan reproduksi dan kesehatan ternak serta pembuatan pakan sapi potong. Pelatihan berlangsung selama dua hari dengan sesi pemberian materi, tanya jawab dan praktek. Kegiatan pelatihan berjalan dengan baik dan lancar serta kondusif. Kegiatan ini dapat menambah wawasan para peternak dalam usaha peningkatan hasil produksinya. Hasil dari proses pelatihan ini, para peternak dapat mencegah terjadinya kasus penyakit pada ternaknya dan dapat membuat pakan ternak ruminansia yang nutrisinya sesuai dan sederhana.
\end{abstract}

Kata Kunci: pelatihan, produksi ternak, ruminansia.

Artikel diterima : 16 November 2020 direvisi : 20 November 2020 disetujui : 1 Desember 2020 


\section{Pendahuluan}

Pemerintah Kabupaten Kediri terus berupaya dalam peningkatan kemampuan, ketrampilan dan pendapatan masyarakat. Salah satu upaya tersebut dengan mengadakan pelatihan yang diberikan oleh Dinas Ketahanan Pangan dan Peternakan Kabupaten Kediri. Pelatihan tersebut memiliki tema "Peningkatan Produksi Peternakan Ruminansia oleh Dinas Ketahanan Pangan dan Peternakan Kabupaten Kediri”. Acara ini dilaksanakan pada beberapa tempat di daerah kabupaten Kediri, salah satunya di desa Jarak, kecamatan Plosoklaten.

Masyarakat desa Jarak kecamatan Plosoklaten kabupaten Kediri, mayoritas berprofesi sebagai petani dan peternak. Sedangkat jenis ternak yang paling banyak dipelihara adalah ternak jenis ruminansia terutama sapi potong dan kambing. Semakin berkembangnya ilmu pengetahuan tentang peternakan maka pemerintah kabupaten Kediri berupaya untuk memberikan tambahan wawasan kepada peternak agar mendapatkan hasil yang optimal. Pengembangan ternak ruminansia sapi dan kambing merupakan salah satu komoditas strategis yang dapat mendukung ketahanan pangan dalam penyediaan kebutuhan pangan protein asal ternak. Inovasi teknologi peternakan ruminansia sapi dan kambing perlu dilakukan sehingga diperoleh produktivitas ternak ruminansia yang optimal (Pinardi, 2019).

Beberapa persoalan yang sering dihadapi peternak yaitu rendahnya nutrisi pakan yang diberikan kepada ternak mereka, rendahnya hasil produksi serta permasalahan kesehatan dan sulitnya betina untuk bunting. Dinas Ketahanan Pangan dan Peternakan Kabupaten Kediri berupaya memberikan solusi kepada peternak melalui pelatihan yang narasumbernya dari Universitas Islam Kadiri.

Narasumber dalam pelatihan tersebut dari Program Studi Peternakan Fakultas Pertanian Universitas Islam Kadiri. Adapun materi yang disampaikan yaitu tentang manajemen reproduksi dan kesehatan ter- nak serta pelatihan pembuatan pakan sapi potong.

Kesehatan ternak merupakan aspek yang sangat penting dalam keberhasilan berternak karena ternak mampu berproduksi dengan optimal jika dalam kondisi sehat (Mekonnen et al., 2006). Kesehatan ternak berkaitan dengan sistem pengelolaan ternak mulai dari keamanan asal ternak, pakan, air dan lingkungan yang terjadi pada setiap mata rantai kegiatan (Bahri, 2008).

Biosecurity merupakan salah satu tindakan penting dan strategis guna mencegah masuk atau keluarnya suatu penyakit dalam kawasan peternakan. Elemen dasar biosecurity antara lain isolasi, pembersihan, desinfeksi, dan pengaturan lalu lintas di kawasan. Aspek kesehatan hewan, antara lain: pengetahuan mengenai penyakit agar ternak menjadi resisten, pencegahan penyakit ke dalam peternakan dan pengobatan penyakit dengan penggunaan obat-obatan serta bahan kimia secara aman.

Manajemen reproduksi ternak harus memiliki pengetahuan mengenai tandatanda birahi yang memadai. Umumnya peternak lebih senang memanfaatkan teknologi inseminasi buatan (IB) untuk perkawinan ternaknya. Hal ini disebabkan karena peternak mendapatkan jaminan semen dari pejantan unggul dan memiliki keleluasaan untuk memilih bangsa ternak yang diinginkan (Toelihere, 1993). Pada ternak sapi sebaiknya dika-winkan pada umur 24-30 bulan sapi sudah beranak pertama (Sudono et al., 2005). Umur beranak pertama kurang dari 2 (dua) tahun dapat menurunkan produktivitasnya, baik untuk beranak lagi.

Kebutuhan ternak akan zat gizi terdiri atas kebutuhan untuk hidup dan pertumbuhan ternak. Kandungan nutrisi yang mencukupi dapat meningkatkan pertumbuhan bagi ternak, sehingga pertumbuhan ternak tersebut akan normal (Anggraeni et al., 2008). Dengan demikian pakan yang diberikan harus memenuhi kebutuhan ternak akan nutrien, palatabel, ekonomis, dan baik untuk kesehatan ternak. Kendala yang dihadapi peternak adalah terbatasnya pengetahuan akan pemilihan 
bahan pakan dan pengolahannya agar menjadi pakan yang ekonomis tetapi memiliki kandungan nutrisi yang cukup.

\section{Pelaksanaan dan Metode}

Kegiatan pelatihan ini dirancang untuk membekali masyarakat, khususnya peternak desa Jarak, kecamatan Plosoklaten, kabupaten Kediri berupa ketrampilan pengolahan pakan, penyelesaian masalah reproduksi dan tindakan pertolongan pertama untuk ternak yang sakit. Pelatihan dilaksanakan atas kerjasama antara Dinas Ketahanan Pangan dan Peternakan (DKPP) Kabupaten Kediri, dengan Program Studi Peternakan, Fakultas Pertanian Universitas Islam Kadiri. Metode yang digunakan dalam program ini adalah pelatihan di dalam kelas dan praktek pembuatan pakan ternak.

Pelatihan adalah suatu proses yang meliputi serangkaian tindak (upaya) yang dilaksanakan dengan sengaja dalam bentuk pemberian bantuan kepada tenaga kerja yang dilakukan oleh tenaga profesional. Kepelatihan dalam satuan waktu yang bertujuan untuk meningkatkan kemampuan kerja peserta dalam bidang pekerjaan tertentu guna meningkatkan efektivitas dan produktivitas dalam suatu organisasi (Hamalik, 2001).

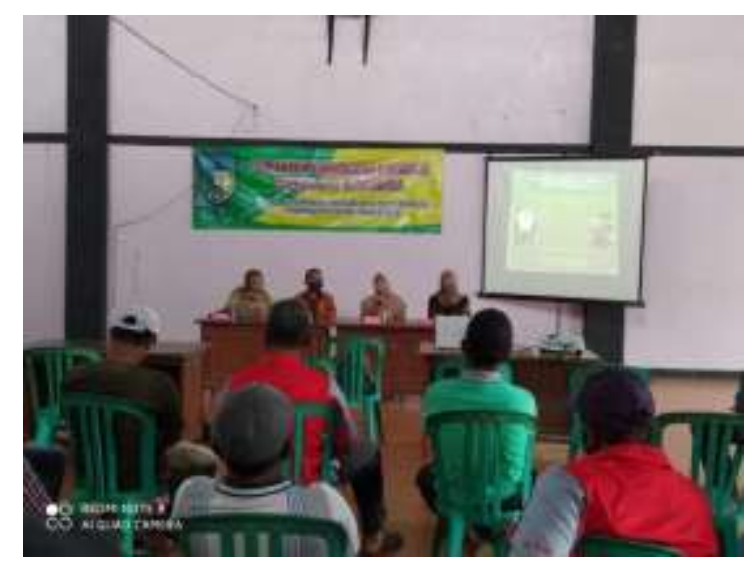

Gambar 1. Pembukaan Pelatihan

Pelatihan dilaksanakan di balai desa Jarak, Plosoklaten kabupaten Kediri pada hari Senin dan Selasa tanggal 26 dan 27 Oktober 2020. Acara dibuka oleh Dinas
Ketahanan Pangan dan Peternakan Kabupaten Kediri yang diwakili oleh Ibu drh. Catur Nanik, kemudian kepala desa Jarak dan perwakilan dari kantor Kecamatan Plosoklaten.

Pelatihan pada hari pertama adalah mempelajari tentang manajemen reproduksi dan kesehatan ternak ruminansia. Materi ini disampaikan oleh Ibu Ertika Fitri Lisnanti, drh., M.Si, dosen dari Program Studi Peternakan Fakultas Pertanian Universitas Islam Kadiri. Topik yang disampaikan be-rupa materi sederhana yang bisa dilakukan oleh peternak dalam proses pencegahan dan penanggulangan beberapa kendala repro-duksi dan penyakit yang umum menjangkit ternak ruminansia.

Kegiatan pelatihan pada hari pertama berjalan cukup lancar dengan dihadiri sebanyak 30 orang peternak sapi potong yang berasal dari perwakilan anggota gabungan kelompok tani (gapoktan) yang ada di desa Jarak kecamatan Plosoklaten kabupaten Kediri. Pelatihan ini dilaksanakan dalam 2 (dua) sesi yaitu penyampaian materi dan tanya jawab. Kegiatan ini dimulai pukul 09.30-12.30.

Pelatihan pada hari kedua yaitu mempelajari tentang pembuatan pakan sapi potong. Materi ini disampaikan oleh Bapak Amiril Mukmin, S.Pt., MP, dosen dari Program Studi Peternakan Fakultas Pertanian Universitas Islam Kadiri.

Kegiatan pelatihan pada hari kedua berjalan cukup lancar dengan dihadiri sebanyak 27 (dua puluh tujuh) peternak sapi potong yang berasal dari perwakilan anggota gabungan kelompok tani (gapoktan) yang ada di desa Jarak kecamatan Plosoklaten kabupaten Kediri. Pelatihan ini dilaksanakan dalam 2 (dua) sesi, yaitu penyampaian materi dan dilanjutkan praktek pembuatan konsentrat dan pengolahan pakan. Kegiatan ini dimulai pukul 09.30 dan selesai pukul 12.30.

\section{Hasil dan Pembahasan}

Dalam sambutannya, Kepala Desa menyampaikan bahwa pelatihan ini dilak- 
sanakan atas permintaan warga desa Jarak. Materi yang disampaikan juga sangat penting dan sangat membantu warga terutama peternak. Kepala desa menjelaskan bahwa peningkatan hasil produksi ternak juga akan meningkatkan pendapatan peternak itu sendiri. Sehingga beliau mengharapkan untuk peserta pelatihan menerapkan ilmu yang didapatkan dari pelatihan ini dengan sebaik-baiknya.

Secara umum usaha peternakan tidak dapat terlepas dari konsep segi tiga produksi, yaitu breeding (bibit), feeding (pakan), dan management (tata laksana) (Amam dan Harsita 2019). Ketiga komponen dalam segitiga produksi ini saling terkait sehingga tidak bisa diabaikan salah satunya, atau akan berdampak pada produksi ternak yang tidak optimal.

Tema hari pertama dalam pelatihan yaitu penanganan gangguan reproduksi dan kesehatan ternak. Sapi yang dipelihara oleh masyarakat desa Jarak sebagian besar adalah sapi betina dan dan ada beberapa sapi jantan. Sapi betina dipelihara untuk tujuan menghasilkan pedet (breeding) sedangkan sapi jantan dipelihara untuk menghasilkan daging (fattening). Secara potensi, sapi betina mampu beranak menghasilkan pedet setiap tahun dengan jarak beranak 12 bulan, namun kenyataanya sapi betina yang dipelihara oleh peternak di desa Jarak memiliki jarak beranak yang lebih dari 14 bulan, bahkan banyak diantaranya yang sampai di atas 18 bulan. Kondisi ini diduga karena tata laksana dalam pemeliharaan ternak, terutama terkait pencatatan reproduksi belum dilaksanakan dengan baik.

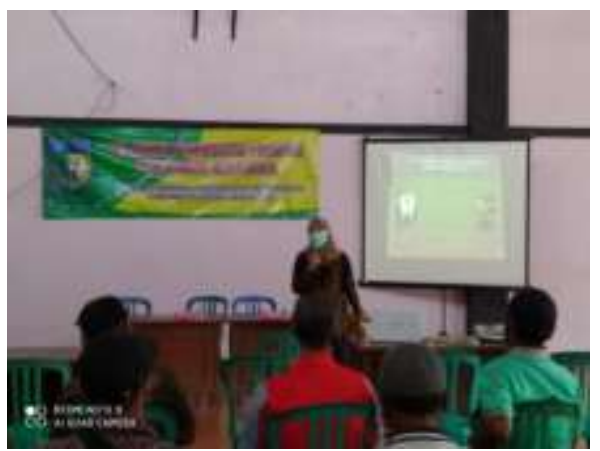

Gambar 2. Pelatihan hari pertama
Proses inseminasi buatan (IB) yang telah dilakukan berulang kali tetapi tidak menghasilkan kebuntingan merupakan hal yang paling banyak dikeluhkan oleh para peternak. Dalam pelatihan ini, pemateri memberikan penjelasan dari awal proses fertilisasi (bersatunya sel sperma dan sel telur), efisiensi reproduksi, serta berbagai gangguan reproduksi. Beberapa peternak masih kurang memahami gejala birahi yang ditunjukkan oleh sapi betina, yaitu ternak gelisah, nafsu makan berkurang, suka menaiki dan dinaiki sesamanya, sering berteriak, dan dari keluar lendir yang bening dan tidak berwarna.

Tiap sapi memiliki ciri-ciri atau sikap yang berbeda dalam menunjukkan birahinya, sehingga membuat peternak sering terlambat mengetahui jika sapi mereka dalam kondisi birahi. Selain hal tersebut, kendala yang dihadapi peternak yaitu penentuan kapan waktu yang tepat dalam pelaksanaan inseminasi buatan. Menurut Djanah (1985), bahwa 0- 6 jam setelah gejala birahi terlalu awal untuk diinseminasi yaitu 610 jam dan 20-30 jam setelah birahi merupakan waktu yang baik untuk inseminasi buatan dan setelah 20-30 jam setelah birahi sudah terlambat untuk inseminasi.

Beberapa faktor yang menyebabkan rendahnya prosentase kebuntingan yaitu fertilitas dan kualitas mani beku yang jelek/rendah, inseminator yang kurang terampil, peternak yang kurang terampil dalam mendeteksi birahi, pelaporan yang terlambat dan pelayanan inseminator yang lambat serta kemungkinan adanya gangguan reproduksi/kesehatan sapi betina. Dengan adanya diskusi dan pelatihan ini diharapkan ketrampilan peternak dalam pendeteksian birahi dan penentuan waktu inseminasi yang tepat akan meningkat sehingga diharapkan prosentase kebuntingan dari proses inseminasi buatan akan meningkat.

Selain permasalahan tingkat keberhasilan IB, prolapse vaginal juga pernah terjadi kepada ternak mereka. Penanganan prolapse vaginal wajib dilakukan oleh dokter hewan. Tetapi kendala yang dihadapi adalah kadangkala dokter hewan datang 
terlambat dikarenakan medan lokasi ternak yang sulit dijangkau. Menyiasati hal tersebut, peternak bisa melakukan beberapa langkah agar jaringan nya tidak rusak sambil menunggu penanganan dari dokter hewan setempat. Langkah tersebut antara lain, ternak ditempatkan ditempat pada kemiringan 5-15 cm lebih tinggi bagian belakang, kemudian vagina yang keluar dibersihkan dengan air bersih atau air yang steril. Langkah yang selanjutnya akan dilakukan oleh dokter hewan yaitu reposisi, irigasi, injeksi antibiotik dan penjahitan vulva. Menurut Trisunawati (2011), prolapse vaginal kemungkinan disebabkan karena :

1. Pada akhir kebuntingan, kadar esterogen terlalu tinggi.

2. Seringkali terjadi apabila proses partus tidak alami.

3. Induk sudah berumur tua, terutama pada kelahiran kembar atau anak terlalu besar.

4. Perkandangan dan tatalaksana kurang baik meliputi pakan, kandang curam.

5. Kondisi menurun dari sejarah keluarga sehingga menurun atau faktor heriditas.

6. Kadar esterogen tinggi sebagai akibat ovari cystic atau pakan hijauan yang mengandung phytoesterogen sehingga jaringan vagina menjadi sangat longgar dan mudah terdorong keluar.

Salah satu kendala yang perlu diperhatikan dalam upaya peningkatan produksi ternak sapi potong adalah kesehatan hewan. Menurut Trisunawati (2011), penyakit atau kondisi sakit ialah terjadinya perubahan fisiologis pada individu yang merupakan akibat dari kausal atau penyebab penyakit. Perubahan fisiologis umum yang mudah diamati antara lain : perubahan suhu tubuh, peradangan (yang ditandai dengan kesakitan, peningkatan suhu tubuh, kemerahan dan kebengkakan), tidak ada atau berkurangnya nafsu makan dan depresi.

Dalam pelatihan ini kita berdiskusi beberapa penyakit yang sangat umum dialami oleh para peternak antara lain : kembung dan diare. Dalam pelatihan ini, peternak diharapkan bisa mencegah terjadinya penyakit itu muncul. Pengobatan penyakit tetap wajib dilakukan oleh dokter hewan setempat.

Pada awal musim penghujan, kembung sering menyerang ternak para warga. Faktor yang bisa menyebabkan kembung terjadi antara lain tingginya tanaman leguminosa dan pucuk/tanaman muda segar yang dikonsumsi, penggunaan konsentrat yang terlalu tinggi serta faktor genetik dari hewan itu sendiri. Gejala yang sering muncul perut sebelah kiri menggembung, nafsu makan menurun, nafas cepat dan dangkal. Pencegahan yang bisa dilakukan oleh peternak antara lain, ransum pakan mengandung cukup mineral terutama garam dan air segar, hindarkan pakan dalam jumlah yang berlebihan saat perut kosong, hindarkan terlalu banyak pemberian pakan tanaman leguminosa, pakan dilayukan dahulu sebelum diberikan kepada ternak.

Penyakit pada ternak sapi selanjutnya yang paling sering terjadi adalah diare. Diare merupakan masalah yang sangat umum muncul pada semua umur sapi, walaupun yang sering terjadi pada anak sapi. Diare pada ruminansia terjadi karena beberapa agen penyakit yang bersifat pathogen. Penanganan pada diare tergantung pada penyebab diare tersebut terjadi. Anak sapi penderita diare akan mengalami kekurangan cairan yang mengandung garam mineral atau elektrolit sehingga terjadi dehidrasi dan asidosis yang dapat menyebabkan kematian. Kerugian ekonomi yang dirasakan oleh peternak akibat biaya obat dan tenaga pengobatan, kematian dan gangguan pertumbuhan pada anak sapi yang masih bertahan hidup (Anderson et al., 2003) Banyak faktor penyebab diare anak sapi antara lain gangguan metabolik, penyakit yang disebabkan oleh nutrisi (Payne, 1989), agen penyakit infeksius maupun non-infeksius (Ralston et al., 2003).

Diare non-infeksius bisa disebabkan karena adanya perubahan pakan yang mendadak, untuk itu peternak wajib melakukan perubahan pemberian pakan secara bertahap sedikit demi sedikit agar ternak dapat beradaptasi dengan baik, 
sehingga tidak menyebabkan diare. Selain itu, stress terhadap perubahan lingkungan juga bisa menyebabkan diare pada ternak. Maka dari itu, peternak wajib menjada ternaknya agar tidak terkena paparan stress.

Pengendalian pada diare umumnya masih menekan gejala simptomatisnya saja sehingga penyakitnya belum tuntas dan sering muncul kembali. Pemberian vaksin dan antibiotik dapat dilakukan sebagai tindakan pencegahan dan pengobatan, tetapi wajib dilakukan oleh dokter hewan setempat. Jika ternak sudah mengalami diare, dengan tetap ditangani dokter hewan, peternak dapat memberikan cairan elektrolit sebagai pengganti cairan yang keluar karena diare. Larutan ini bisa dibuat langsung oleh peternak, karena pembuatan cairan elektrolit ini sangat sederhana. Bahan pembuatannya yaitu 1 sendok makan gula : 1 sendok makan garam : 2-2,5 liter air. Pengelolaan lingkungan perlu diperhatikan mulai dari sanitasi kandang, kandang kering, sirkulasi udara kandang, cahaya yang masuk, dkk. Apabila ling-kungan dikelola dengan baik, maka diha-rapkan diare tidak akan menginfeksi ternak.

Tema kegiatan pelatihan kedua adalah pembuatan pakan sapi potong. Sedangkan topik yang disampaikan pada sesi pelatihan pembuatan pakan sapi potong antara lain adalah: segi tiga produksi ternak, kebutuhan nutrisi sapi potong, pakan sapi potong, pengolahan pakan. Kegiatan pelatihan pembuatan pakan sapi potong ini tidak hanya dengan penyampaian materi, tetapi juga dengan praktek pembuatan pakan ternak.

\section{Segitiga produksi ternak}

Berdasarkan hasil diskusi dengan peserta pelatihan, ternyata para peternak belum menerapkan konsep segitiga produksi. Dari ketiga komponen tersebut, baru bibit yang diperhatikan oleh peternak. Mereka memilih sapi potong unggul dari keturunan simental dan limousine dengan harapan dapat menghasilkan keuntungan yang besar, namun karena dalam pemeliharaannya belum menerapkan pakan dan tatalaksana yang baik ini sehingga produktifitas ternak yang dipelihara masih rendah.

Sapi jantan untuk tujuan penggemukan secara intensif umumnya hanya dipelihara selama 3-4 bulan. Dengan menerapkan konsep segitiga produksi, sapi jantan yang digemukkan mampu menghasilkan pertambahan bobot badan di atas 1,2 $\mathrm{kg} /$ hari. Peternak sapi potong di desa Jarak belum fokus memelihara sapinya secara intensif. Mereka memelihara sapi masih sebagai usaha sampingan dengan berorientasi memelihara sapi hanya sebagai tabungan sehingga produktifitas sapi jantan tidak maksimal.

\section{Kebutuhan nutrisi sapi potong}

Berdasarkan status fisiologisnya, sapi potong betina dapat dibedakan menjadi 4 kategori yaitu pedet, dara, bunting, dan menyusui. Sapi betina dari keempat kategori tersebut memiliki kebutuhan nutrisi dan kemampuan mencerna pakan yang berbeda. Secara kebutuhan jumlah nutrisi, pedet membutuhkan nutrisi yang paling rendah karena ukuran tubuhnya kecil dan orientasi nutrisinya hanya untuk partumbuhan yang masih lambat. Namun demikian, pakan yang diberikan kepada pedet harus berkualitas bagus dengan daya cerna yang tinggi karena sistem pencernaannya belum sempurna sehingga kemampuan dalam mencerna pakan belum maksimal.

Sapi dara memiliki kebutuhan nutrisi yang lebih tinggi daripada pedet karena selain untuk pertumbuhan juga membutuhkan nutrisi untuk sistem reproduksinya. Namun karena sistem pencernaannya sudah sempurna baik dari segi kapasitas maupun kemampuan mencernanya, sapi dara lebih toleran terhadap pakan berkualitas rendah.

Sapi bunting membutuhkan nutrisi untuk memenuhi kebutuhan nutrisi untuk tubuhnya dan untuk pertumbuhan fetus yang ada dalam kandungannya. Kapasitas organ pencernaan sapi bunting menurun akibat terdesak oleh ukuran fetus yang semakin membesar. Dengan demikian, pakan yang diberikan kepada sapi bunting harus lebih bagus supaya dengan jumlah pakan yang sama atau bahkan lebih sedikit 
mampu menyediakan nutrisi siap diserap yang lebih besar.

Nutrisi untuk sapi betina pada masa bunting dan menyusui harus diperhatikan dengan seksama. Asupan nutrisi yang kurang dapat menurunkan nilai kondisi ternak (Body Condition Score = BCS). BCS adalah metode perhitungan semikuantitatif dengan menggunakan interval tertentu untuk mengetahui skala kegemukan. Di wilayah Jawa Timur, perhitungan BCS umumnya menggunakan skala $5(1=$ sangat kurus, $2=$ kurus, 3=sedang, 4=gemuk, 5=sangat gemuk) (Pujiastuti, 2016).

BCS pada induk memiliki hubungan yang erat dengan status cadangan energi tubuh ternak, sedangkan cadangan energi tersebut erat hubungannya dengan gizi yang dikonsumsi (Winugroho, 2002). BCS ideal untuk sapi laktasi atau menyusui adalah 3,0-3,5 (Netika dkk, 2019). Nilai BCS yang turun akibat kurangnya asupan nutrisi pasca beranak dapat menyebabkan komplikasi reproduksi (Malichatin, 2017).

\section{Pakan sapi potong}

Pada dasarnya sapi adalah hewan herbivora, yaitu hewan pemakan tumbuhan. Berdasarkan sistem pencernaannya sapi termasuk hewan ruminansia yang saluran pencernaan bagian lambungnya mengalami modifikasi menjadi 4 (empat) bagian yaitu rumen, reticulum, omasum dan abomasum. Rumen dan reticulum merupakan bagian lambung yang dilengkapi dengan milyaran sel mikroorganisme yang membantu proses pencernaan secara fermentatif. Keberadaan mikroorganisme di dalam rumen dan reticulum ini yang membantu sapi dalam memanfaatkan pakan berserat kasar tinggi dari rumput ataupun limbah pertanian menjadi sumber energy berupa asam lemak terbang (Volatile Fatty Acid = VFA) untuk memenuhi kebutuhan ternak.

Peternak sapi potong di desa Jarak kecamatan Plosoklaten kabupaten Kediri memberikan rumput dan limbah pertanian sebagai pakan untuk sapi yang mereka pelihara. Rumput yang diberikan berupa rumput lapang, gulma dari tanaman pertanian, dan rumput hasil budidaya. Secara kandungan nutrisi dan daya cernanya, rumput merupakan bahan pakan yang bagus untuk ternak ruminansia. Namun karena kondisinya yang masih segar, rumput mengandung air yang cukup tinggi yaitu lebih dari $80 \%$ (bahkan di musim penghujan kadar air hijauan bisa lebih dari $85 \%$ ) sehingga menjadi pembatas dalam konsumsi bahan kering. Artinya, ternak yang hanya diberi pakan dari rumput segar, isi saluran pencernaan akan didominasi air sehingga kebutuhan nutrisi untuk produksi optimal tidak terpenuhi.

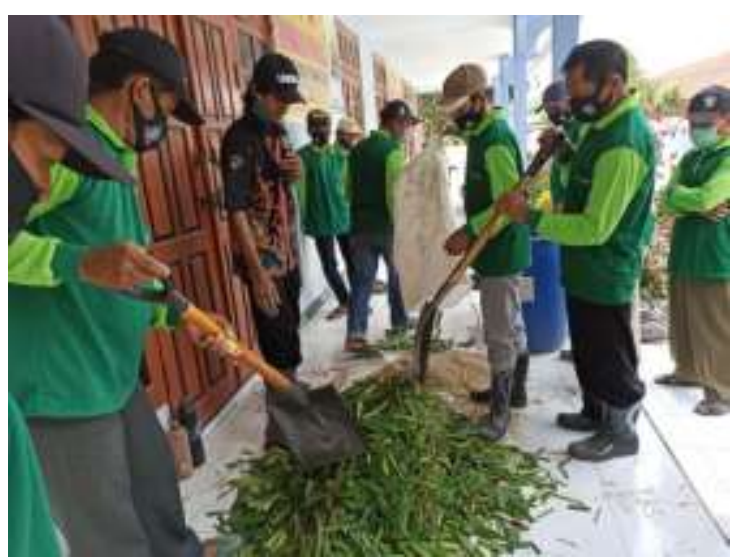

Gambar 3. Praktek Pembuatan Pakan Sapi Potong

Limbah pertanian yang umum digunakan peternak di desa Jarak adalah jerami padi dan jerami jagung. Kedua jenis jerami ini tersedia sangat berlimpah ketika musim panen. Kebanyakan peternak menyimpan limbah pertanian untuk persediaan pakan ketika ketersediaan hijauan berkurang. Namun demikian ada juga peternak yang memberikan limbah pertanian sebagai pakan utamanya sepanjang tahun.

Di daerah agraris limbah pertanian memiliki potensi yang besar dalam mendukung kebutuhan pakan untuk ternak ruminansia. Komoditas tanaman pangan mayoritas yang banyak ditanam petani di pedesaan dan menghasilkan limbah sebagai pakan ternak adalah padi dan jagung (Umiyasih dan Wina, 2008). Faktor utama yang membatasi pemanfaatan limbah pertanian seperti jerami padi dan jagung adalah daya cerna, kandungan protein, dan palatabilitas yang rendah (Yanuartono dkk., 
2019). Kendala tersebut dapat dikurangi antara lain melalui proses fermentasi dan pemberian pakan tambahan (Martaeidjaja, 2003).

Proses fermentasi merupakan perlakuan biologis yang dapat meningkatkan nilai nutrisi limbah pertanian karena dapat memetabolisme lignoselulosa sehingga dapat lebih optimal dicerna oleh mikroorganisme di dalam rumen (Yanuarto dkk., 2019). Pakan tambahan yang yang berpotensi untuk meningkatkan performa sapi potong adalah konsentrat. Konsentrat adalah bahan pakan yang memiliki nilai gizi tinggi. Tingginya nilai gizi pada konsentrat menyebabkan harga konsentrat relatif mahal. Untuk menekan biaya pakan, konsentrat dapat dibuat dari bahan lokal dengan harga murah (Kallo dan Tondok, 2019).

\section{Pengolahan pakan}

Bahan pakan untuk ternak ruminansia di sekitar kita. Beberapa diantaranya dapat kita peroleh secara cuma-cuma dengan hanya membayar tenaga kerja, namun beberapa yang lain harus kita beli karena sudah dijual secara komersial. Bahan-bahan yang harus membeli untuk mendapatkannya biasanya dari kelompok, baik dari kategori sumber serat ataupun sumber konsentrat sudah tersedia melimpah limbah industri pertanian yang diperuntukkan sebagai bahan penyusun konsentrat. Namun demikian, apabila kita mengetahui teknik pembuatannya, menyusun konsentrat sendiri dengan mengoptimalkan bahan-bahan lokal akan dapat menekan harga sehingga lebih murah dibandingkan dengan membeli konsentrat jadi.

Secara umum konsentrat tersusun atas bahan pakan sumber energi, bahan pakan sumber protein, dan bahan tambahan berupa sumber mineral, asam amino, vitamin atau aditif. Bahan pakan lokal sumber protein antara lain bisa menggunakan bekatul, ampas singkong atau onggok, ampok jagung, tepung gaplek, mie afkir, biskuit atau roti afkir, molasses atau tetes, dll. Untuk saat ini, pemilihan tetes sebagai bahan sumber energi perlu diperhitungkan kembali karena tetes mengalami kenaikan harga yang signifikan. Sebelumnya harga tetes hanya berkisar antara $3000-3500 / \mathrm{kg}$, saat ini harganya mencapai 5000-5500/kg.

Bahan pakan lokal sumber protein antara lain dapat dipilih ampas tahu, ampas kecap, bungkil kopra, pollar, urea, dll. Urea yang merupakan pupuk untuk tanaman pertanian dapat dimanfaatkan sebagai sumber protein bagi ternak ruminansia. Dengan imbangan energi yang tepat, urea yang ditambahkan dalam pakan akan diuraikan oleh mikroorganisme rumen untuk memperbanyak sel mikroba. Pada akhirnya sel mikroorganisme ini akan mengalir ke pasca rumen bersama partikel pakan yang lain. Sel mikroorganisme yang terbawa ke pasca rumen akan dicerna oleh enzim pencernaan sebagai sumber protein yang siap diserap oleh tubuh ternak.

Kualitas pakan konsentrat dapat ditingkatkan dengan menambahkan bungkil kacang kedelai. Bahan pakan ini mengandung protein yang terproteksi dari degradasi mikroba di dalam rumen, sehingga harapannya protein dari bungkil kedelai dapat menjadi bypass protein yang langsung tersedia untuk dicerna dan diserap di pasca rumen. Yang perlu diperhatikan dari penggunaan bungkil kedelai adalah harganya. Bungkil kedelai adalah produk impor sehingga harganya sangat dipengaruhi oleh nilai tukar rupiah. Untuk saat ini harga bungkil kedelai cukup mahal sehingga penggunaannya dalam konsentat sapi perlu dipertimbangkan kembali. Berikut adalah contoh formula pakan konsentrat sederhana dan formula pakan konsentrat sangat sederhana berbahan lokal yang dapat dibuat untuk meningkatkan kualitas asupan nutrisi pada sapi potong.

Contoh formula konsentrat sederhana untuk sapi potong sebagai berikut: 1 . Ampok jagung : 20\%, 2. Bekatul : 43\%, 3 . Polar : 20\%, 4. Bungkil kopra : 10\%, 5. Bungkil kacang kedelai : 5\%, 6. Mineral : $2 \%$. Sedangkan contoh formula konsentrat sangat sederhana untuk sapi potong sebagai berikut : 1. Bekatul / ampok jagung : $65 \%$, 2. Bungkil kopra : 33\%, 3. Mineral : 2\%. 
Dengan kualitas bahan yang baik, kedua contoh formula konsentrat di atas mengandung protein kasar sekitar $16 \%$. Angka ini sudah sangat bagus untuk memperbaiki kualitas asupan nutrisi untuk sapi potong, baik jantan ataupun betina. Untuk hasil optimal konsentrat diberikan dalam kondisi kering sebelum pemberian hijauan. Pemberian konsentrat dalam keadaan kering bertujuan untuk merangsang sekresi saliva atau air liur. Saliva mengandung larutan buffer yang dapat mempertahankan $\mathrm{pH}$. Konsumsi konsentrat dapat meningkatkan produksi asam di dalam rumen. Sekresi saliva ketika ternak mengkonsumsi konsentrat dapat menekan resiko asidosis atau penurunan $\mathrm{pH}$ di dalam rumen.

Proses pembuatan konsentrat dipraktekkan bersama para peternak peserta pelatihan ini. Bahan-bahan penyusun konsentrat disediakan oleh panitia. Proses pembuatan konsentrat yang dipraktekkan adalah contoh formula konsentrat sederhana untuk sapi potong dengan bahan-bahan dari ampok jagung, bekatul, polar, bungkil kopra, bungkil kacang kedelai, dan mineral. Peserta pelatihan berpartisipasi aktif dalam praktik pembuatan konsentrat ini.

Bahan pakan sumber serat yang berasal dari limbah pertanian memiliki daya cerna yang rendah, hal ini terjadi akibat penimbunan lignin atau proses lignifikasi. Proses ini menguntungkan dari sisi budidaya pertanian karena dapat memperkokoh batang sehingga tanaman tidak mudah roboh. Namun dari sisi kualitas pakan ternak, proses ini merugikan karena dapat menurunkan daya cerna pakan. Untuk memperbaiki kualitas asupan nutrisi sapi potong dengan pakan berbasis limbah pertanian dapat dilakukan dengan menambahkan konsentrat, baik diberikan secara langsung sebagai pakan lengkap ataupun diproses lebih lanjut menjadi pakan lengkap fermentasi.

Pakan lengkap dapat dibuat dengan menambahkan konsentrat pada sumber serat yang sudah dicacah. Dalam menyusun pakan lengkap, hal yang perlu diperhatikan antara lain adalah ketersediaan pakan dan kebutuhan nutrisi ternak. Berikut adalah contoh formula pakan lengkap yang sesuai diberikan pada sapi potong fase dara dan pada masa awal kebuntungan. Apabila akan diberikan pada sapi betina yang sedang bunting tua atau menyusui maka perlu ditambahkan lebih banyak konsentrat supaya asupan nutrisinya lebih tinggi.

Contoh formula pakan lengkap untuk sapi potong (imbangan dalam bahan kering $60 \%$ sumber serat : $40 \%$ konsentrat) sebagai berikut: 1 . Pakan penguat $4,5 \mathrm{~kg}, 2$. Sumber serat segar $35 \mathrm{~kg}$, atau sebagai berikut: 1 .Pakan penguat $4,5 \mathrm{~kg}, 2$. Sumber serat kering7,5 kg. Sumber serat segar dapat menggunakan rumput yang masih segar, sedangkan sumber serat kering bisa menggunakan limbah pertanian kering berupa jerami padi, jerami jagung, tongkol jagung, kulit kacang tanah, atau bahan lain yang sejenis.

Tahapan proses pembuatan pakan lengkap adalah:

1. Mempersiapakan bahan yang dibutuhkan, bahan yang berukuran besar atau panjang seperti rumput, tongkol jagung, dll dicacah atau digiling terlebih dahulu supaya mudah dalam proses pencampuran;

2. Menimbang bahan-bahan sesuai takaran;

3. Mencampur bahan sampai rata;

4. Campuran sudah menjadi pakan lengkap dan dapat diberikan langsung ke ternak.

Pakan lengkap fermentasi adalah pakan lengkap yang diperam dalam kondisi kedap udara dalam waktu tertentu supaya terjadi aktifitas mikroorganisme anaerob untuk menghasilkan enzim yang mempu mencerna dinding sel tanaman. Formula pakan lengkap fermentasi relatif sama seperti formula pakan lengkap biasa, hanya saja ada penambahan starter untuk mempercepat proses fermentasi. Untuk pakan lengkap yang dibuat dari bahan sumber serat kering, dalam formula ditambahkan air untuk meningkatkan kadar air campuran sampai minimal 35\% supaya mikroorganisme yang membantu proses fermentasi 
dapat tumbuh dengan baik. Berikut adalah contoh formula pakan lengkap fermentasi.

Contoh formula pakan lengkap fermentasi untuk sapi potong sebagai berikut: 1 . Pakan penguat $4,5 \mathrm{~kg}, 2$. Sumber serat segar $35 \mathrm{~kg}$, 3. Tetes 100-200 ml, 4 . MOL atau starter 10-20 ml, 5. Air $500 \mathrm{ml}$ atau sebagai berikut : 1 . Pakan penguat 4,5 $\mathrm{kg}, 2$. Sumber serat kering 7,5 kg, 3. Tetes 100-200 ml, 4. MOL atau starter 10-20 ml, 5. Air 10-12 liter.

Tetes merupakan sumber karbohidrat yang sangat mudah terfermentasi. Penambahan tetes berfungsi untuk mengaktifkan MOL atau starter supaya segera siap bekerja untuk melakukan fermentasi. Penambahan air pada formula dengan sumber serat segar berfungsi untuk memudahkan pencampuran starter dan tetes pada pakan lengkap. Kadar air yang berasal dari sumber serat segar sudah cukup untuk menghasilkan kadar air campuran minimal $35 \%$. Formula dengan sumber serat kering perlu ditambahkan lebih banyak air. Selain berfungsi untuk memudahkan pencampuran starter dan tetes pada pakan lengkap, penambahan air juga berfungsi untuk meningkatkan kadar air campuran supaya mikroorganisme dapat beraktifitas normal dalam proses fermentasi.

Tahapan proses pembuatan pakan lengkap fermentasi adalah:

1. Mempersiapkan bahan yang dibutuhkan, bahan yang berukuran besar atau panjang seperti rumput, tongkol jagung, dll dicacah atau digiling terlebih dahulu supaya mudah dalam proses pencampuran;

2. Menimbang bahan-bahan sesuai takaran;

3. Mencampur bahan sampai rata;

4. Memasukkan campuran pakan lengkap ke dalam silo sambil dipadatkan;

5. Menutup silo untuk menghasilkan kondisi kedap udara;

6. Membiarkan pakan lengkap di dalam silo untuk mengalami proses fermentasi (sekitar 2-4 minggu).
7. Silo dibuka, pakan lengkap fermentasi bisa langsung diberikan ke ternak sebagai pakan tunggal.

Untuk proses fermentasi optimal, silo harus berisi penuh dan padat. Silo yang tidak penuh atau berongga akan berisi oksigen yang menghambat proses fermentasi ananaerob. Proses fermentasi membutuhkan waktu selama 2-4 minggu. Selama proses fermentasi berlangsung, sebaiknya silo tidak dibuka supaya oksigen tidak masuk dan mengganggu proses fermentasi. Namun demikian, sebelum masa 2 minggu pakan tetap bisa diberikan kepada ternak, namun karena proses fermentasi belum selesai, peningkatan kualias pakan belum maksimal.

Proses fermentasi dikatakan berhasil jika berbau khas fermentasi (asam manis seperti tape) dan warna terlihat segar (tidak banyak berubah dari warna asalnya). Proses fermentasi dikatakan gagal jika berbau busuk dan atau warna berubah menjadi gelap.

Pembuatan pakan lengkap fermentasi dipraktekkan menggunakan formula sumber serat segar, yaitu menggunakan sumput gajah. Dalam kegiatan praktik, peserta cukup aktif dan antusias. Dalam praktik disediakan silo berupa kantong plastik dan drum plastik. Keduanya memiliki keunggulan dan kelemahan masingmasing. Dalam praktek, hijauan dicacah secara manual menggunakan sabit sehingga batang rumput tidak bisa hancur bahkan beberapa cukup runcing. Mempertimbangkan hal tersebut, dalam praktek dipilih silo dari drum plastik supaya silo tidak rusak terkena batang rumput yang runcing. Hasil praktik akan dipriksa kembali 4 minggu setelah praktek pembuatan.

\section{Penutup}

\section{Simpulan}

Berdasarkan hasil pelaksanaan kegiatan pengabdian masyarakat oleh Dinas Ketahanan Pangan dan Peternakan Kabupaten Kediri yang bekerjasama dengan Program Studi Peternakan Fakultas Pertanian 
Universitas Islam Kadiri berupa pelatihan peningkatan produksi peternakan ruminansia di desa Jarak kecamatan Plosoklaten kabupaten Kediri dapat ditarik kesimpulan sebagai berikut: 1 . Kegiatan pelatihan berjalan dengan baik dan lancar serta kondusif; 2. Kegiatan pelatihan dapat menambah wawasan para peternak dalam usaha peningkatan hasil produksinya; 3 . Hasil dari pelatihan ini, para peternak dapat mencegah terjadinya kasus penyakit pada ternak dan dapat membuat pakan ternak ruminansia yang nutrisinya sesuai.

\section{Saran}

Saran yang dapat diberikan pada kegiatan ini yaitu : 1 . Materi yang telah disampaikan sebaiknya diterapkan dengan baik oleh para peternak; 2. Hendaknya kelompok ternak dapat selalu bersamasama dalam pengelolaan peternakan agar hasil yang didapat lebih optimal.

\section{Ucapan terima kasih}

Ucapan terima kasih disampaikan kepada semua pihak yang telah berperan dalam kegiatan pelatihan peningkatan produksi peternakan ruminansia di desa Jarak kecamatan Plosoklaten kabupaten Kediri terutama kepada Dinas Ketahanan Pangan dan Peternakan Kabupaten Kediri, sehingga kegiatan ini dapat berjalan dengan lancar dan dapat memberikan manfaat untuk masyarakat khususnya para peternak.

\section{Daftar Pustaka}

Amam dan P.A. Harsita. 2019. Tiga Pilar Usaha Ternak: Breeding, Feeding, Management. Jurnal Sain Peternakan Indonesia. 14 (4) : 431-439.

Anderson, D.C., D.D. Lress, M.M. Bernardini, K.C. Davis, D.L. Boss and D.E. Doornbos. 2003. The Effect of scours on calf weaning weight. Prof. Anim. Sci. 19 : 399403.

Bahri, S. 2008. Beberapa aspek keamanan pangan asal ternak di Indonesia.
Pengembangan Inovasi Pertanian. 1(3): 225-242.

Djanah, D. 1985. Mengenal Inseminasi Buatan. CV. Simplex. Jakarta.

Hamalik, Oemar. 2001. Pengembangan Sumber Daya Manusia Manajemen Pelatihan Ketenagakerjaan Pendekatan Terpadu. Jakarta : Bumi Aksara.

Kallo, R., dan A.R. Tondok. 2019. Membuat Pakan Konsentrat Untuk Ternak Sapi Potong. BPTP Balitbangtan Sulawesi Selatan.

Malichatin, H. 2017. Penilaian Body Condition Scoring (BCS) dan Peran Nutrisi dalam Reproduksi Sapi Potong. Dina Peternakan Kabupaten Lebak.

Martawidjaja, M. 2003. Pemanfaatan Jerami Padi Sebagai Pengganti Rumput Untuk Ternak Ruminansia Kecil. Wartazoa. 13 (3) : 119-127.

Mekonnen, M. H., Asmamaw, K., Courreau, J. F., 2006. Husbandry practices and health in smallholder dairy farms near Addis Ababa, Ethiopia. Prev Vet Med. 74(2):99107.

Netika, M., R. Darsono, B. Utomo, I. Mustofa, Ismudiono, dan T.W. Suprayogi. 2019. Hubungan Antara Body Condition Score (BCS) dengan Produksi Susu Sapi Perah Friesian Holstein (FH). Ovozoa. 8 (2) : 89-93.

Pinardi, D., Gunarto, A., Santoso. 2019. Perencanaan Lanskap Kawasan Penerapan Inovasi Teknologi Peternakan Prumpung Berbasis Ramah Lingkungan. Jurnal Ilmiah Peternakan Terpadi. 7(2) : 251-262.

Pujiastuti, R. 2016. Perhitungan Body Scoring Condition (BCS) pada Sapi Perah. UPT Inseminasi Buatan. Dinas Peternakan Provinsi Jawa Timur.

Pyne, J.M. 1989. Metabolic and Nutritional Diseases of Cattle. Blackwell Scientific Publication. Pp: 1-40. 
Ralston, B.J., T.A. Mcallister and M.E. Olson. 2003. Prevalence and infections pattern of naturally acquired giardiasis and cryptosporidiosis in range beef calves and their dams. Vet. Parasitol. 114: 113-122.

Sudono, A., R. F. Rosdiana, dan B. S. Setiawan. 2005. Beternak Sapi Perah Secara Intensif. Agromedia Pustaka. Jakarta.

Toelihere, M. R. 1993. Inseminasi Buatan pada Ternak. Penerbit Angkasa. Bandung.

Trisunawati, P. Pengantar Ilmu Penyakit Hewan. 2011. Universitas Brawijaya Press.

Umiyasih, U. dan E. Wina. 2008. Pengolahan dan Nilai Nutrisi Limbah Tanaman Jagung Sebagai Pakan Ternak Ruminansia. Wartazoa. 8 (3) : 127-136.

Winugroho, M. 2002. Strategi Pemberian Pakan Tambahan Untuk Memperbaiki Efisiensi Reproduksi Induk Sapi. Jurnal Litbang Pertanian. 21 (1) : 19-23.

Yanuartono, H. Purnamaningsih, S. Indarjulianto, A. Nururrozi, S. Raharjo, dan N. Haribowo. 2019. Perlakuan Biologis Dengan Memanfaatkan Fungi Untuk Meningkatkan Kualitas Pakan Ternak Asal Hasil Samping Pertanian, Jurnal Peternakan Sriwijaya. 8 (2) : 18-34. 